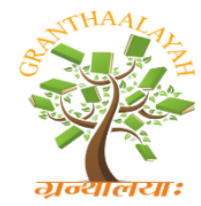

INTERNATIONAL JOURNAL OF RESEARCH GRANTHAALAYAH A knowledge Repository

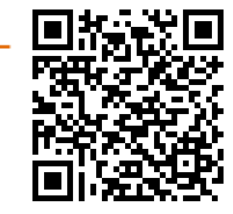

Social

\title{
LEARNING DIFFICULTIES OF STUDENTS IN LEARNING EFL
}

\author{
S. Devibala ${ }^{1}$, Mrs. Pankajam. $\mathrm{R}^{2}$ \\ ${ }^{1}$ M.A., MEd Scholar, RVS College of Education, Sulur, India \\ ${ }^{2}$ M.Sc., M.Sc (Psy), M.Phil, M.Ed., M.Phil, (Edu), Assistant Professor in Physical Science, RVS \\ College of Education, India
}

DOI: https://doi.org/10.29121/granthaalayah.v5.i5(SE).2017.1976

\begin{abstract}
The study aimed to identify the learning difficulties in English as a second language among ninth standard students. In the present study survey method was used. The investigator adopted the survey method to study the difficulties in learning English as a second language among the 9th standard students. . Investigator selected only 300 ninth std school students as sample in Coimbatore district using stratified random sampling. The findings reveal that based on the factors the maximum difficulty is found to be in the Speaking $(45 \%)$ skill. Next to speaking, vocabulary and reading are found to be difficult for the selected ninth standard students. Grammar seems to be least difficult for their level. Demographic variables such as gender and medium of instruction has no impact on LD in learning EFL among students, whereas type of school and locality has significant impact on LD in learning EFL among students.
\end{abstract}

Keywords: LD (Learning Difficulties); EFL (English as Foreign Language); L1 (First Language); L2 (Second Language).

Cite This Article: S. Devibala, and Mrs. Pankajam. R. (2017). "LEARNING DIFFICULTIES OF STUDENTS IN LEARNING EFL." International Journal of Research - Granthaalayah, 5(5)SE, 87-92. https://doi.org/10.29121/granthaalayah.v5.i5(SE).2017.1976.

\section{Introduction}

English is a language which has great reach and influence; it is taught all over the world under many circumstances. English as a Second Language is also known as English for speakers of other languages (ESOL), English as an additional language (EAL) and as English as a foreign language (EFL). The precise usage, including the different use of the terms ESL and ESOL in different countries, is described below. These terms are most commonly used in relation to teaching and learning English as a second language, but they may also be used in relation to demographic information EFL, English as a foreign language, indicates the teaching of English in a non-English-speaking region. Typically, EFL is learned either to pass exams as a necessary part of one's education, or for career progression while one works for an organization 
or business with an international focus. EFL may be part of the state school curriculum in countries where English has no special status; it may also be supplemented by lessons paid for privately.

Language teaching practice often assumes that most of the difficulties that learners face in the study of English are a consequence of the degree to which their native language differs from English. Language learners often produce errors of syntax, vocabulary, and pronunciation thought to result from the influence of their L1, such as mapping its grammatical patterns inappropriately onto the L2, pronouncing certain sounds incorrectly or with difficulty, and confusing items of vocabulary known as false friends. This is known as L1 transfer or "language interference". However, these transfer effects are typically stronger for beginners' language production, and SLA research has highlighted many errors which cannot be attributed to the L1, as they are attested in learners of many language backgrounds (for example, failure to apply 3rd person present singular -s to verbs, as in 'he make' not 'he makes').

Difficulties in acquiring knowledge and skills to the normal level expected of those of the same age, especially because of mental disability or cognitive disorder or some other reason is termed as learning difficulty.

Some students may have very different cultural perceptions in the classroom as far as learning a second language is concerned. Cultural differences in communication styles and preferences are also significant. For example, a study looked at Chinese ESL students and British teachers and found that the Chinese learners did not see classroom discussion and interaction as important but placed a heavy emphasis on teacher-directed lectures.

Students who are ELLs are distinctly different from students with LDs, yet certain cases in which persistent difficulties with language skills are involved may indicate that a student's difficulties are due to both being an ELL and having an LD. IDEA (2004) states that ELLs should be excluded from LD identification; however, school teams receive referrals in which language difficulty appears to be attributable to something beyond having an L1 other than English. This happens when the following factors are present:

- Ability/achievement discrepancy: Based on observation of what the student comprehends and does in class, he or she appears to have ability, but has difficulty actually demonstrating that knowledge when asked, even in a conversational format.

- Processing difficulties: Part of the theoretical model of LD is that these students do not process information the way normally achieving students do. There is no specific assessment to test for this characteristic. Rather, teachers may make conclusions about behavior and peer relationships noticed over time, which indicate processing difficulties of the student in question.

- Expressive (oral language and writing) and receptive (reading and listening comprehension) difficulties in both the student's L1 and English.

- Difficulties with reading in both the student's L1 and English. 
When these factors are present, teachers are asked to consider them carefully in conjunction with input from all involved with the student in order to facilitate an informed decision about possible classification.

The imperative to address students' needs at an early point in school is often in conflict with the need to allow language proficiency to develop before assessing a student as having an LD. As previously mentioned, it can take ELLs 5 to 7 years to develop academic English language skills (Chamot \& O'Malley, 1994; Cummins, 2000). Theoretically, an ELL could participate in middle and high school programming for 6 years and not know if he or she has an LD until adulthood and long after the opportunity for public school remediation has passed. Therefore, it is imperative to define at the earliest point in a student's life whether special education services are needed (Lyon et al., 2001) while allowing for typical language difficulties that ELLs face. Given the situation, it is also imperative that ESL, content area, and special education teachers collaborate to help differentiate ELLs who are experiencing natural language acquisition development from those with special needs.

The major LD's for EFL learners are

- Speaking \& Pronunciation Difficulties

- Grammar Difficulties

- Vocabulary Difficulties

- Reading Difficulties

\section{Research Design}

The study aimed to identify the learning difficulties in English as a second language among ninth standard students. In the present study survey method was used. The investigator adopted the survey method to study the difficulties in learning English as a second language among the $9^{\text {th }}$ standard students. . Investigator selected only 300 ninth std school students as sample in Coimbatore district using stratified random sampling.

\section{HYPOTHESES: 1}

There is no significant difference on learning difficulties in English as a second language among ninth standard students based on the language skills.

Table 1: Frequency and percentage difference in learning English as a second language among ninth standard students based on the language skills.

\begin{tabular}{|c|c|c|c|c|c|c|c|c|c|c|c|c|}
\hline \multirow[b]{2}{*}{ FACTORS } & \multicolumn{3}{|c|}{ P25 } & \multicolumn{3}{|c|}{ P50 } & \multicolumn{3}{|c|}{ P75 } & \multicolumn{3}{|c|}{ P100 } \\
\hline & P1 & $\mathbf{F}$ & $\%$ & $\mathbf{P 2}$ & $\mathbf{F}$ & $\%$ & P3 & $\mathbf{F}$ & $\%$ & P4 & $\mathbf{F}$ & $\%$ \\
\hline Grammar & 10 & 25 & 8.3 & 20 & 94 & 31.3 & 20 & 94 & 31.3 & 28 & 35 & 11.6 \\
\hline Vocabulary & 10 & 85 & 28.3 & 19 & 67 & 27.3 & 20 & 50 & 16.6 & 29 & 98 & 32.6 \\
\hline Speaking & 10 & 135 & 45 & 11 & 17 & 5.6 & 20 & 97 & 32.3 & 25 & 50 & 16.6 \\
\hline Reading & 48 & 79 & 26.3 & 65 & 74 & 24.66 & 78 & 97 & 32.3 & 98 & 50 & 16.6 \\
\hline $\begin{array}{l}\text { Learning } \\
\text { Difficulty } \\
\end{array}$ & 48 & 78 & 26 & 65 & 75 & 25 & 78 & 73 & 24.3 & 98 & 74 & 24.6 \\
\hline
\end{tabular}


From the above table percentiles namely P25, P50, P75 and P100 are given which reveals the difficulty levels. It is inferred that $26 \%$ of the ninth students have high difficulty level in learning English as a second language, $25 \%$ of the ninth students have moderate difficulty level in learning English as a second language, $24.3 \%$ of the ninth students have mild difficulty level in learning English as a second language and $24.6 \%$ of the ninth students have no difficulty in learning English as a second language. Based on the factors the maximum difficulty is found to be in the SPEAKING (45\%) skill. Next to speaking, vocabulary and reading are found to be difficult for the selected ninth standard students. Grammar seem to be least difficult for their level

\section{HYPOTHESES: 2}

There is no significant difference in the learning difficulties in English as a second language among ninth standard students based on their gender.

Table 2: Mean score difference and t-ratio of learning difficulties in English as a second language among ninth standard students based on their gender.

\begin{tabular}{|l|l|l|l|l|l|l|l|l|}
\hline Factors & SUBJECT & N & Mean & S.D & df & t-value & p-value & Result \\
\hline \multirow{4}{*}{ GENDER } & MALE & 147 & 60.88 & 16.605 & & & & \\
\cline { 2 - 5 } & FEMALE & 153 & \multirow{2}{*}{66.22} & 17.147 & 300 & 2.738 & .007 & N.S \\
\cline { 2 - 5 } & TOTAL & 300 & & & & & & \\
\hline
\end{tabular}

The above table shows that mean score difference in the learning difficulties in English as a second language among ninth standard students based on their gender. According to the table the calculated t-value is not statistically significant at 0.05 levels and hence, the hypothesis 2 is accepted. It can be concluded that there is no significant difference in the learning difficulties in English as a second language among ninth standard students based on their gender.

\section{HYPOTHESES: 3}

There is no significant difference in the learning difficulties in English as a second language among ninth standard students based on their locality.

Table 3: Mean score difference and t-ratio of learning difficulties in English as a second language among ninth standard students based on their locality.

\begin{tabular}{|l|l|l|l|l|l|l|l|l|}
\hline Factors & SUBJECT & N & Mean & S.D & df & t-value & p-value & Result \\
\hline \multirow{3}{*}{ LOCALITY } & RURAL & 60 & 55.28 & 15.458 & & & & \\
\cline { 2 - 5 } & URBAN & 240 & \multirow{2}{*}{65.68} & 16.843 & 300 & 4.345 & 0.000 & S \\
\cline { 2 - 5 } & TOTAL & 300 & & & & & & \\
\hline
\end{tabular}

The above table shows that mean score difference in the learning difficulties in English as a second language among ninth standard students based on their locality. According to the table the calculated t-value is not statistically significant at 0.05 levels and hence, the hypothesis 3 is 
rejected. It can be concluded that there is significant difference in the learning difficulties in English as a second language among ninth standard students based on their locality.

\section{HYPOTHESES: 4}

There is no significant difference in the learning difficulties in English as a second language among ninth standard students based on their type of school

Table 4: Mean score difference and t-ratio of learning difficulties in English as a second language among ninth standard students based on their type of school.

\begin{tabular}{|l|l|l|l|l|l|l|l|l|}
\hline Factors & SUBJECT & N & Mean & S.D & df & t-value & p-value & Result \\
\hline \multirow{3}{*}{$\begin{array}{l}\text { TYPE OF } \\
\text { SCHOOL }\end{array}$} & GOVT & 136 & 66.14 & 16.685 & & & & \\
\cline { 2 - 5 } & PRIVATE & 163 & \multirow{2}{*}{61.44} & 17.178 & 300 & 2.389 & .004 & S \\
\cline { 2 - 5 } & TOTAL & 300 & & & & & & \\
\hline
\end{tabular}

The above table shows that mean score difference in the learning difficulties in English as a second language among ninth standard students based on their type of schools. According to the table the calculated t-value is not statistically significant at 0.05 levels and hence, the hypothesis 4 is rejected. It can be concluded that there is significant difference in the learning difficulties in English as a second language among ninth standard students based on their type of schools.

\section{HYPOTHESES: 5}

There is no significant difference in the learning difficulties in English as a second language among ninth standard students based on their medium of instruction.

Table 5: Mean score difference and t-ratio of learning difficulties in English as a second language among ninth standard students based on their medium of instruction.

\begin{tabular}{|l|l|l|l|l|l|l|l|l|}
\hline Factors & SUBJECT & $\mathbf{N}$ & Mean & S.D & df & t-value & p-value & Result \\
\hline \multirow{4}{*}{ MEDIUM } & TAMIL & 128 & 65.86 & 16.653 & & & & \\
\cline { 2 - 5 } & ENGLISH & 171 & \multirow{2}{*}{62.05} & 17.191 & 300 & 1.923 & .055 & N.S \\
\cline { 2 - 5 } & TOTAL & 300 & & & & & & \\
\hline
\end{tabular}

The above table shows that mean score difference in the learning difficulties in English as a second language among ninth standard students based on their medium of instruction. According to the table the calculated t-value is not statistically significant at 0.05 levels and hence, the hypothesis 5 is accepted. It can be concluded that there is no significant difference in the learning difficulties in English as a second language among ninth standard students based on their medium of instruction.

\section{Conclusion}

The findings of the study reveals that $26 \%$ of the ninth students have high difficulty level in learning English as a second language, $25 \%$ of the ninth students have moderate difficulty level 
in learning English as a second language, $24.3 \%$ of the ninth students have mild difficulty level in learning English as a second language and $24.6 \%$ of the ninth students have no difficulty in learning English as a second language. Based on the factors the maximum difficulty is found to be in the Speaking (45\%) skill. Next to speaking, vocabulary and reading are found to be difficult for the selected ninth standard students. Grammar seems to be least difficult for their level. Demographic variables such as gender and medium of instruction has no impact on LD in learning EFL among students, whereas type of school and locality has significant impact on LD in learning EFL among students.

\section{References}

[1] Golden, S. A. R. (2011). Problems and Prospectus of Distance Education. Quality Enhancement In Distance Education For Life Long Learning, 1(1), 343-344.

[2] Golden, S. A. R. (2016). RURAL STUDENTS' ATTITUDE TOWARDS ENGLISH AS MEDIUM OF INSTRUCTION IN HIGHER EDUCATION - AN ANALYSIS. International Journal of Research, 3(Special Issue - 16), 1-10.

[3] Golden, S. A. R. (2017). Attitude of Students and Teachers towards E- Learning - An Analysis. Recent Research in Social Science \& Humanities, 1, 5-10.

[4] Golden, S. A. R. (2017). Recent Research In Social Science \& Humanities.

[5] Laxmi, R. A., \& Kumar, K. A. S. AWARENESS AND ATTITUDES OF CONSUMERS IN USING INTERNET FOR ONLINE PURCHASE.

[6] Regi, S. B. (2016). Prospectus \& Challenges Of Women Entrepreneurs-A Study With Special Reference To Tirunelveli District. International Journal Of Scientific Research And Modern Education, 786, 792.

[7] Regi, S. B. (2016). Prospectus \& Challenges Of Women Entrepreneurs-A Study With Special Reference To Tirunelveli District. International Journal Of Scientific Research And Modern Education, 786, 792.

[8] Regi, S. B., \& Golden, S. A. R. (2014). A DESCRIPTIVE STUDY ON THE ROLE OF CONSUMER PSYCHOLOGY AND BEHAVIOUR IN PRODUCT PURCHASING”. Indian Streams Research Journal, 3(12), 1-6. 